\title{
HELENISMO E CRISTIANISMO PRIMITIVO: ENCONTROS E CONFRONTOS
}

\section{PAULO SÉRGIO DANTAS VASCONCELOS ${ }^{1}$}

RESUMO: A proposta do nosso trabalho é analisar a relação entre helenismo e cristianismo à luz das principais doutrinas, a saber, cosmologia, teodiceia (existência e propriedades de Deus) e antropologia as quais foram desenvolvidas por grandes espíritos do pensamento grego e cristão. Cumpre, preliminarmente, estabelecer alguns critérios para a análise de um tema que, por sua natureza propõe, antes de tudo, comparar dois universos de ideias fundamentalmente distintos. O cristianismo não é grego, e a síntese com a cultura helenista não se deu senão sob a égide de conflitos e aporias que marcaram definitivamente o espírito desse encontro que, ocorrido nos primeiros séculos de nossa era, ainda hoje motiva questionamentos.

PALAVRAS-CHAVE: Helenismo; Cristianismo; Cosmologia; Teodiceia; Antropologia.

ABSTRACT : The purpose of our work is to analyze the relationship between Hellenism and Christianity in the light of the main doctrines, namely cosmology, theodicy (properties of God) and anthropology that were developed by great spirits of Greek and Christian thought. It is necessary, first of all, to establish some criteria for the analysis of a theme which, by its nature, proposes, first of all, to compare two universes of fundamentally different ideas. Christianity is not Greek, and the synthesis with the Hellenistic culture was only under the aegis of conflicts and aporias that definitely marked the spirit of this encounter, which occurred in the first centuries of our era, still today causes questions.

KEYWORDS: Hellenism; Christianity; Cosmology; Theodicy; Anthropology

\section{Parte I}

Primeiramente, deve-se evitar comparar, sem as devidas precauções, o estado incoativo do pensamento cristão primitivo com as especulações refinadas do pensamento grego muitas vezes enriquecidas de elementos orientais. Do mesmo modo, deve-se entender a reciprocidade de empréstimos e influências entre a cosmovisão cristã e a filosofia grega, muito mais que tãosomente a inferência do domínio desta àquela. Julgar que houve unicamente a colaboração do pensamento grego nos escritos da tradição apostólica e apologista é negligenciar como muitos autores da escola comparatista, exemplos históricos que contrariam notadamente essas

\footnotetext{
${ }^{1}$ Prof. de Filosofia da Universidade do Estado da Bahia (UNEB) e Universidade Católica do Salvador (UCSAL). Doutor em Educação pela Universidade Federal da Bahia (UFBA). E-mail: paulo_filo@hotmail.com/ paulo.vasconcelos@ucsal.br.
} 
posições. Sabe-se, por exemplo, que o "imperador Juliano, procurando dar novas forças ao culto pagão em declínio, tentou copiar em seu proveito a organização hierárquica e o serviço social da Igreja cristã" (Pépin.1983.p.16). Assim também é o caso de Apolônio de Tiana que "tentaram erigir no rival pagão de Jesus" ( Idem.p.17) e mesmo o de Amélio, neoplatônico do fim do século III que "acolhe uma doutrina do Logos como verbo subsistente de Deus, em favor da qual evoca Heráclito ao mesmo tempo que confessa sua dependência relativamente ao prólogo do 4 evangelho, cuja autor qualifica de 'Bárbaro' " (Idem). Portanto, o acontecimento cristão não deixou de exarar sua presença no Helenismo sem contudo ter que sacrificar sua originalidade.

Preservado em sua essência, o cristianismo primitivo confronta suas teses de conteúdo querigmático e soteriológico com a filosofia pagã sem necessariamente abdicar do diálogo oportuno com estoicos, epicuristas, céticos e "ecléticos" em todos os sentidos do termo, já que as filosofias do helenismo são, em sua maioria, sistemas "híbridos". A "démarche" cristã se coloca a partir de algumas doutrinas que se constituem como um sólido patrimônio apostólico e que, se torna em sua grande parte, a única orientação dos "padres filósofos" até o concílio de Nicéia em 325.

A Filosofia somente aparecerá na história do cristianismo no momento que alguns cristãos tomam posição em relação a ela, seja para domiciliá-la ,seja para condená-la ou mesmo para utilizá-la em favor da apologética cristã . O termo Filosofia aparecerá neste contexto com o sentido de "Sabedoria Pagã", que conservará durante séculos. Mesmo nos séculos XII e XII, os termos "santos" e "filósofos" significarão diretamente a oposição entre as concepções do mundo elaboradas por homens privados das luzes da fé e as dos padres da Igreja falando em nome da revelação cristã.

É fato, que muitos destes padres se converteram ao cristianismo bastante tarde e depois de terem recebido uma educação grega, eram inclinados a uma orientação mais "diplomática" com a Filosofia quando esta servia muitas vezes como auxílio para a busca de Deus. Outros, ao contrário, que não mantiveram em suas especulações nenhum vínculo com as pesquisas filosóficas adotaram uma atitude resolutamente negativa em presença de doutrinas que não despertavam qualquer interesse.

$\mathrm{Na}$ linha de historiadores como Johann G. Droysen, para o qual o cristianismo surge do helenismo e dele toma as direções mais notáveis de seu primeiro desenvolvimento, Jaeger considera de importância decisiva para a afirmação do cristianismo como religião universal o processo de três séculos de expansão da cultura grega desencadeado pelas conquistas de 
Alexandre. Realmente, em torno da Bíblia irá organizar-se uma civilização com feições próprias, mas em razão de uma dialética vital entre o kerygma cristão, cujo maior esforço será ultrapassar os limites da Judéia, e esta cultura de muitos séculos e largas dimensões geográficas, a cultura grega.

Neste encontro histórico, a língua grega, falada em todas as sinagogas das cidades do Mediterrâneo, é fator decisivo. Ela põe ao alcance do judeu helenizado e do gentio a doutrina cristã, cuja forma literária, nesta tarefa de conversão, é muitas vezes grega.

Descrevendo o desenvolvimento histórico da religião cristã durante os primeiros séculos, Jaeger (1994) o vê como um processo contínuo de tradução das fontes hebraicas com o objetivo de oferecer ao mundo uma compreensão cada vez mais adequada de seu conteúdo.

Este processo se teria iniciado com os evangelistas, cujas interpretações doutrinárias se faziam conforme as categorias da Lei e os Profetas, dentro da tradição messiânica de Israel. A partir daí se daria o encontro da cultura clássica com o Cristianismo em proporções sempre mais amplas, o que já se pode ver na carta de São Clemente Romano aos coríntios, da última década do século $3^{\mathrm{a}} \mathrm{D}$. Nela o bispo de Roma procura justificar pela razão as exortações morais dirigidas à igreja que já ao apóstolo Paulo oferecera motivos de preocupação. Nesta carta, conforme procura mostrar Jaeger, pode perceber-se uma teoria filosófica grega interpretada em sentido cristão, bem como um método novo que, posteriormente, no século IV, os Padres da Igreja, combinando a autoridade da Bíblia e a razão, aplicariam em suas argumentações.

No século II, a rápida expansão do Cristianismo, antecipando as grandes controvérsias entre cristãos e pagãos do século seguinte, leva as elites intelectuais do mundo greco-romano, postas em contato mais direto com a doutrina cristã, a lhe oporem uma primeira reação. Nesta época o Cristianismo, considerado a filosofia dos bárbaros, é severamente julgado pela mentalidade pagã com as categorias da cultura clássica. Canibalismo, ateísmo, subversão política, eis as principais acusações, a que os Padres da Igreja procuraram responder apologeticamente, aproveitando as circunstâncias para tornar simpático à causa de Cristo o público pagão. As reações mais negativas vêm ligadas a homens de cultura formados na tradição clássica, entre os quais se citam Tácito, Marco Aurélio, Galeno e Celso. Criticam-se no Cristianismo os seus fundamentos, a ausência do pensamento crítico e o apoio integral na fé.

Já entre os pensadores cristãos da mesma época podem perceber-se duas orientações opostas. Uma, representada por Justino e Atenágoras, na linha de Fílon, procura absorver a tradição grega na doutrina cristã. Quer mesmo aplicar ao Cristianismo algumas categorias 
espirituais da cultura grega e reconhece nela certos paralelismos com a doutrina cristã. A outra, de feições claramente anti-helênicas, defendida por Taciano e Tertuliano, o africano, denuncia e condena a helenização do cristianismo. Tertuliano, em particular, separa razão e fé, e repete a idéia de um paralelo entre cristianismo e helenismo em termos filosóficos.

Compreende-se portanto o contato do Cristianismo com o Helenismo como um desafio. Desafio de uma religião que reivindicava para si a posse da verdade, lançado à única cultura intelectual do mundo que tentara ser universal e o conseguira. Nestes termos, o cristianismo teria buscado na tradição grega a segurança de sua própria universalidade. Isto não nos deve levar à conclusão precipitada de que a doutrina de Cristo adquiriu proporções mundiais em razão exclusiva do apoio intelectual que lhe ofereceu o helenismo. Estamos diante de uma questão complexa e da maior importância que, examinada em dimensões mais amplas, põe em julgamento a força espiritual do cristianismo, seu poder de conversão e os motivos que levaram o mundo helenístico, preso pelas raízes à cultura grega, a deixar-se por ele seduzir e a adotá-lo. Por outro lado não podemos ver a helenização do pensamento cristão como um processo unilateral, sem relação alguma com as necessidades internas da civilização grega da época. A antiga religião dos deuses olímpicos, após a dissolução da polis, deixara um vazio de tal natureza que as correntes filosóficas mais significativas do mundo greco-romano foram levadas a preencher com a maior espiritualidade, nos termos de uma necessidade religiosa não racional. Quando aparece o cristianismo, torna-se conveniente e, por que não dizer, necessário à mentalidade pagã examinar esta fé que reúne adeptos tão fieis, avança por todas as terras e, curiosamente, com recursos intelectuais emprestados à própria tradição clássica, parece aplicar com eficiência as formas necessárias para fazer-se entender por todos, gentios e cristãos.

\section{Parte II}

$\mathrm{Na}$ segunda parte de nosso trabalho pretendemos mostrar que as "disputas" mais significativas entre cristãos e gregos se manifestaram a partir de algumas doutrinas.As Cosmologias, as Antropologias e as Teodicéias e Teologias dos cristãos são documentos legítimos atestando, em muitos momentos, o divórcio entre eles e a Paidéia grega. Do mesmo modo, por essas mesmas doutrinas, percebemos o movimento de transição entre uma cultura e outra, ou seja, a filosofia pré-socrática é prioritariamente cosmológica, o filosofar ático se constitui enquanto questão antropológica e a partir do cristianismo a "busca de Deus" caracterizará o pensamento humano até o Renascimento. A transversalidade entre essas 
doutrinas impossibilita o exame separado de cada uma delas. Desse modo, analisaremo-nas em conjunto, privilegiando sobretudo os possíveis desentendimentos entre cristãos e gregos:

\section{Cosmologia Cristã x Cosmologia Grega.}

A concepção cristã do universo é fixada,em suas linhas mestras, deste o início do século II; denominada de judeu-cristã, porque é a mesma que o cristianismo herdara do antigo testamento.Essa fórmula da criação ex-nihilo, era por sinal, ela própria de origem bíblica ( Mac-2. 7,28) e devia torna-se o termo técnico utilizado por todos cristãos para designar o próprio fato da criação. Baseado na Revelação, Justino ensina que o mundo foi criado por Deus, ou mais exatamente, pelo Logos. Taciano parece conceber que o Verbo "projetou" o mundo para fora de si mesmo.Teófilo de Antioquia professa que "Deus produziu todas as coisas que são, de não existentes à existência". Em síntese, a tese da criação "do nada" representa na tradição judeu-cristã uma conquista e é em defesa desse patrimônio que Orígenes confessa sua dificuldade em conceber uma matéria eterna e incriada a que o Demiurgo tivesse dado forma conforme o Timeu de Platão. Segundo o alexandrino, o suposto erro dos adversários "resulta de uma concepção antropomórfica de Deus. Incapazes de pensar em Deus,salvo em conceitos humanos, concebem-Lhe a atividade à maneira da do escultor" (Gilson, 1995, p.62). Entretanto, mesmo adotada pelos padres, essa tese cosmogônica não encontra justificativa no livro Sabedoria de Salomão do Antigo Testamento ${ }^{2}$. A razão dessa possível discordância de posições judeu-cristãs encontra-se,muito provavelmente, na origem alexandrina do livro ${ }^{3}$.

Em verdade, a tese cosmogônica de Orígenes (a doutrina da sucessão infinita de mundos finitos) encontra-se contaminada de concepções estoicas mas , nem por isso teve comprometida sua base cristã. Contra os estoicos, essa doutrina não admite, como faz a escola do Pórtico (a tese do Eterno Retorno) uma repetição idêntica de mundos pois, se assim compreendesse negaria respectivamente a doutrina cristã da Redenção e o princípio bíblico do Livre Arbítrio.

A demiurgia do deus platônico assumida, em parte, pelo panteísmo estoico é combatida veementemente pela concepção judeu-cristã do mundo criatura. O deus de Platão subordina a matéria dando-lhe ordem e beleza. Esta matéria eterna é portanto configurada e planificada segundo o modelo das Idéias; enquanto Iahweh, do nada tudo faz, matéria e forma, princípio e fim.Em outros termos, a divindade ordenadora e demiúrgica platônica reafirma sua

\footnotetext{
2 "a mão todo- poderosa de Deus criou o mundo a partir de uma matéria informe" (XI,17).

${ }^{3}$ Foi principalmente em Alexandria que se operou o sincretismo judeu-helenístico que teve como mais importante manifestação a tradução grega da bíblia hebraica: a Septuaginta.
} 
contingência com o mundo ao contrário do Deus judeu-cristão que sem necessidade ou qualquer dependência, pela palavra cria todas as coisas

\section{Imagem Cristã de Deus X Imagen Helênica do Divino}

Encontra-se já na teodiceia de Aristides, um dos primeiros apologetas, um conceito de Deus que contrapõe o monoteísmo rigoroso do cristianismo às crenças dos bárbaros que adoraram elementos naturais, às dos gregos que atribuíram aos seus deuses fraquezas e paixões humanas, e às dos judeus que, admitindo embora um só Deus, servem melhor os anjos do que a ele.Essa posição, assumida por Aristides se constituirá como um dos pilares de toda edificação do cristianismo como uma crítica das divindades greco-romanas. Essa clivagem entre a imagem cristã de Deus e o teísmo da filosofia grega pode já ser vista na atitude de Paulo na Primeira Epístola aos Coríntios I,17 - II,16 :

Onde está o sábio? Onde está o letrado? Onde o pesquisador das coisa deste século? Não transformou Deus a sabedoria do mundo em loucura?Porque, na sabedoria de Deus, já que o mundo não conhece a Deus pela própria sabedoria,aprouve a Deus, pela loucura da pregação,salvar os que crêem. Os judeus, pois, reclamam sinais, e os gregos buscam a sabedoria; nós, porém, anunciamos um Cristo crucificado, escândalo para os judeus e loucura para os não-judeus,Cristo é o poder de Deus e sabedoria de Deus. Pois a loucura é mais sábia que os homens (...). (Coríntios 1:15)

$\mathrm{O}$ ataque de Paulo dirige-se contra a falsa sabedoria persuasiva, os métodos da retórica grega; estabelece a distinção antropológica entre o homem racional ,psíquico, e o homem espiritual, pneumático cristão mas, antes de tudo mostra que a verdadeira fé não se demonstra; a fé é vivida muito mais que inteligida. Portanto o Deus de Paulo é "loucura" para os gregos que submetem à "inteligência e à necessidade"4 todo seu o Olimpo. Mas antes em Atenas 5 , o Paulo fideísta de Corintos dá lugar a um pregador cristão que antes de tudo procura ser compreendido, compondo boa parte do seu discurso por uma hábil utilização de concepções de natureza platônica e estóica como : "O Deus que fez o mundo(...) não habita em templos construídos por mãos humanas" ou "se somos de linhagem divina,não devemos pensar que a divindade seja algo parecido com ouro,prata,pedra,expressão de arte e imaginação humana"

Essas atitudes paulinas, ora litigiosa, ora conciliadora configuram, de um modo geral,as duas grandes tendências do pensamento cristão ao longo da História. De um lado a tradição que afirma o cristianismo através desse diálogo com a filosofia grega,do outro, a tradição que

\footnotetext{
4 “ O nascimento deste mundo teve lugar por uma mistura dessas duas ordens, a necessidade e a inteligência (...)" Platão, Timeu 48a

${ }^{5}$ Atos dos Apóstolos (XVII,16-34).
} 
rejeita decisivamente qualquer apoio nesta ${ }^{6}$.A apologética do gnóstico cristão Clemente vê na lei mosaica e na Filosofia grega a função soteriológica e pedagógica de condução a Deus. Do mesmo modo que, anteriormente, Justino havia "domiciliado" os filósofos como participantes do Logos integral só manifestado em Cristo. Porém, do lado oposto a essa tendência, Orígenes ,contra Celso, reivindica a unicidade do seu Deus assim como, Tertuliano pela doutrina do "Testemunho da Alma" reclama a herança cristã da imagem de Deus na alma humana e condena por extensão a "sabedoria profana que temerariamente pretende sondar a natureza e os decretos de Deus" e, assim arremata o padre africano : "filosofia esta, onde as próprias heresias vão pedir seus petrechos".

Ainda dentro das análises Teológicas tomamos agora como provocação a tese do prof. Juan Antonio Estrada onde o mesmo afirma a "continuidade que se dá no cristianismo primitivo com a imagem de Deus dos grandes sistemas filosóficos"7. Ele julga que "o cristianismo se conecta com a tradição parmenídea-platônica-aristotélica que defende a imutabilidade e a impassibilidade de Deus, no marco de uma metafísica da necessidade”. Ou seja, o Deus cristão se mantém imutável e impassível como o divino grego.Logo, segundo Estrada é possível verificar "um afastamento do Deus bíblico, tanto na concepção hebraica como cristã"

Contrapondo-nos a essa posição, vemos no Antigo Testamento a imagem de um Deus passional, mas que age com justiça e muitas vezes indignação ante os acontecimentos históricos.Enfim, trata-se de um Deus que aparece implicado na contingência da História e a serviço da aliança entre criador e criaturas.Do mesmo modo, os livros do Novo Testamento conservam em nossa opinião, a importância do homem e da História. É a imagem do Deus Amor que se identifica conosco pelo Deus-Encarnado e este, enquanto mediação e promessa, nos conduz ao Deus-Transcendência.

Platão não legitima a ideia judeu-cristã de Criação, assim, postula a matéria eterna ${ }^{8}$ configurada pelo demiurgo, do mesmo modo, Aristóteles radicaliza a transcendência divina na imagem do motor-imóvel (ato puro, forma pura, contemplação de si mesmo). Já a Providência estóica sendo imanência, compreende Deus como Alma do mundo ${ }^{9}$.Em síntese, o deísmo grego, de um modo geral, ergue a imagem de um ser divino ora imanente, ora transcendente

\footnotetext{
${ }^{6}$ Justino, Clemente, por exemplo, afirmam o cristianismo como um humanismo, uma sabedoria, uma Paidéia. Paralelamente, Tertuliano, Orígenes. etc. fundarão sua fé pelo signo da rejeição de toda cultura profana ${ }^{7}$ ESTRADA, 2004. p.71

8 Não há em nenhum momento da obra de Platão esclarecimento sobre essa matéria é ao mesmo tempo não-ser mas que no entanto recebe as formas.

${ }_{9}^{9}$ Alma do Mundo, O Demiurgo, O Bem, A Razão são aspectos do Deus platônico ( Cf. Jaeger,1994, p.875 ).
} 
ao mundo mas que não conhece a liberdade posto que é determinado pela necessidade. $\mathrm{O}$ Cristianismo,"vendo" Deus muito mais na alma humana que no mundo, põe por um giro antropológico, uma Religião da Liberdade no lugar de uma Filosofia da Necessidade.A dimensão pessoal do Deus trinitário ${ }^{10}$ é portanto, a marca de originalidade dessa "Filosofia Bárbara" que veio escandalizar os gentios submetendo a razão à loucura da fé.

\section{Antropologia Cristã X Antropologia Grega}

A concepção paulina da natureza humana pela dimensão tripartite (corpo, alma e espírito) estabelece certa originalidade à antropologia cristã ${ }^{11}$ que será adotada por seus "irmãos" como marca da clivagem com o pensamento grego. O homem cristão é carne na medida em que se revela a fragilidade e transitoriedade da sua existência; é alma na medida em que essa fragilidade é compensada pela sua vitalidade; é espírito,ou seja, manifestação superior da vida e do conhecimento, pela qual o homem pode entrar em relação com Deus (Cf. Vaz, p.61). Encontramos no helenismo, principalmente no estoicismo de Sêneca, Epicteto e Marco Aurélio ( Estoá romana) uma certa "contaminação" da cosmovisão judeu-cristã como, por exemplo, a noção de pecado, o fundamento da fraternidade entre os homens, a necessidade do perdão, o amor ao próximo etc.Mas foi,sobretudo, a partir do conceito da "Vontade" humana que Sêneca mais se apropria daquilo que podemos chamar de patrimônio cristão : a Liberdade humana .

A Vontade como faculdade independente do entendimento é o princípio que instaura a metafísica da pessoa no cristianismo. Não mais submetida ao intelecto (como na ética grega), a vontade é livre pois, o homem é liberdade ${ }^{12}$. Portanto, parece ser possível identificar na antropologia da Antigüidade tardia empréstimos da religião cristã mesmo quando, em essência, helenismo e cristianismo sejam, em essência, distintos.

Contudo, a concepção cristã do homem não se constitui enquanto Theoria que se expõe por um discurso de pretensões lógico-demonstrativas (como a Filosofia grega) mas, antes por uma localização deste, enquanto sujeito, na dimensão histórica. Em Agostinho, síntese maior desse "encontro", temos a construção de uma imagem de homem submetida à "peregrinação"

\footnotetext{
${ }^{10}$ As grandes controvérsias no seio da Igreja nascente giram em torno do "problema cristológico": O Docetismo ( concepção segundo a qual Jesus não teria verdadeiro corpo); O Gnosticismo ( compreende um divórcio entre os dois Testamentos); Monarquianismo ( Jesus seria um “segundo Deus"), Montanismo ( fé em um reino terrestre de Cristo, fé em uma Parusia próxima), Arianismo (nega a divindade-igualdade de Jesus ) etc.

${ }^{11}$ É discutível, se o pneuma do estoicismo romano possa ser comparado com o que os cristãos chamam de Espírito.A distinção, cremos, encontra-se principalmente no princípio material daquele.

12 Encontramos já em pensadores cristãos como Agostinho preceitos das filosofias da existência. O próprio Sartre afirma em sua peça Bariola que a liberdade nasceu com os ensinamentos de Cristo.
} 
agônica de cada um de nós em nossas vidas. A história deixa de ser história do mundo para ser história da salvação do indivíduo. Vista como um ser-para-Deus, a alma humana, muito mais que substância inteligível (psyché) é a imagem do criador, a marca da saudade da condição edêmica.

Os cristãos não aceitam a concepção grega da metempsicose da alma apresentada no Fedon de Platão. A ressurreição dos mortos, tese paulina que escandalizou Atenas, implica no retorno também do corpo à vida ${ }^{13}$. A perene união de corpo e alma parece constituir-se como um absurdo para os gregos que viam na morte a possibilidade de superação do corpo "cárcere da alma" e fonte de todo negatividade. O mal tão-somente como efeito da 'vontade' humana e não mais naturalizado no corpo é o signo vitorioso do homem cristão entendido como criatura una e unitária de um Deus soberanamente Bom de onde nenhum mal poderia provir.

Portanto,sendo o homem obra magna de Deus, a antropologia cristã não estaria condicionada à dimensão política ou cosmopolita como criam os helenos mas posta na direção de uma escatologia salvífica; ou seja, o homem vive neste mundo mas não para este mundo.

\section{Considerações Finais}

Helenismo e cristianismo não constituem uma unidade de espíritos. Contudo, não é também possível concebê-los por absoluta divergência. Julgamos que, o resultado expressivo desse "encontro" manifesta uma aproximação de temas comuns sem que ocorra entretanto o sacrifício da essência de ambos, pois se perdessem aquilo que os caracteriza, não saberíamos hoje precisamente identificá-los. Por exemplo, o "conhece-te a ti mesmo" socrático reaparece em Agostinho não como efeito de um confisco mas, como parte de uma nova mensagem que se aproxima daquilo que foi outrora elementos da religiosidade grega. Não negamos com isso que haja uma "comunidade temática" entre as concepções gregas e cristãs de Deus, do mundo ou mesmo do homem porém rejeitamos que esse encontro tenha gerado um terceiro domínio o qual pudéssemos denominar de cultura heleno-cristã. À luz da razão, o pensamento grego se afasta do mito. Pela força da fé, o cristão para ele retorna. Assim, concordamos com Fraile quando este conclui de modo contundente que o filósofo acata a autoridade da evidência; o crente acata a evidência da autoridade ( cf. apud.U. Zilles. p. 48 )

\footnotetext{
${ }^{13}$ A questão da duração da união de corpo e alma pode ser respondida por Gregório de Nissa ( sec. IV ). O capadócio afirma que o homem se torna invisível em conseqüência da decomposição dos elementos que entram na formação do seu corpo. Mas nem por isso se rompe o nexo da alma com as partes constitutivas deste mesmo corpo. Ela lhes permanece necessariamente ligada. Essa doutrina inspira-se em duas ideias essencialmente cristãs: a doutrina da ressurreição futura do corpo e na convicção de que o homem é uma natureza composta de corpo e alma.
} 
Por fim, nossa leitura desse encontro, helenismo e cristianismo, não pretende a proscrição de qualquer das doutrinas analisadas ou mesmo negligenciar de modo sectário outras visões sobre o mesmo assunto.Não é também de nosso interesse confrontar a sabedoria pagã à sabedoria cristã,muito menos opor a razão à fé mas fundamentalmente o propósito ( que aqui, muito mais se inicia que se esgota!) de entender o contributo desse encontro para a edificação do pensamento humano.

\section{REFERÊNCIAS BIBLIOGRÁFICAS}

BÍBLIA. Bíblia TEB. São Paulo: Ed. Loyola. 1995

ESTRADA, A. J. Deus nas Tradições Filosóficas: Aporia e Problemas da Teologia Natural. São Paulo: Paulos. 2004.

GILSON. E.; BOEHNER, P. História da Filosofia Cristã: Desde as Origens até Nicolau de Cusa. Petrópolis: Vozes. 1998.

JAEGER, W. W. Paidéia: A Formação do Homem grego. $3^{\mathrm{a}}$ ed. São Paulo: Martins Fontes. 1994

VAZ, H.C. L. Antropologia Filosófica I. São Paulo: Ed. Loyola. 1991

PEPIN, Jean, «Helenismo e cristianismo», in A Filosofia Medieval, do séc. I ao século $X V$, vol. 2 de Châtelet, François (dir.), História da filosofia, ideias, doutrinas, Rio de Janeiro: Jorge Zahar. 1983.

ZILLES, U. Fé e Razão no Pensamento Medieval. Porto Alegre: EDIPUCRS, 1993. 